\title{
東京都区部に㧈ける飲食店立地と食情報の地域特性に関する研究 THE GEOGRAPHICAL CHARACTERISTICS OF RESTAURANT DISTRIBUTION AND EATING INFORMATION WITHIN TOKYO WARDS AREA
}

\author{
石綿朋葉*1, 後藤春彦*2, 吉江 俊*3 \\ Tomoha ISHIWATA, Haruhiko GOTO and Shun YOSHIE
}

\begin{abstract}
In Tokyo, the accumulation of various restaurants is realized as resources of food culture. Nowadays, "eating experiences" in restaurants is getting important. However, the study on the quality of eating experiences and its geographical characters has hardly been conducted. Thus, it is important to reveal the empirical value of eating in the urban area. The purpose of this study is to identify the geographical characteristics of restaurants accumulation and "eating experiences" within Tokyo wards area. Through this research, the following has been identified:
\end{abstract}

1) The geographical distribution trend of restaurants accumulation,

2) The typology of eating experiences and its differences among station areas.

Keywords: Eating environment, Restaurant distiribution, Eating information, Eating experiences, Geographical charactaristics, Tokyo wards area 食事環境，飲食店立地，食情報，食の経験，地域特性，東京都区部

\section{1 章 緒言}

\section{1-1 研究の背景}

都市における人々の活動の中に、遊興することが挙げられる。そ のひとつが飲食することである ${ }^{11}$ 。実際に、東京における多国籍か つ多様な飲食店の集積は、盛り場の魅力の一つとなっており、更に こうした飲食店は、日常・非日常を問わず、交流の場・娛楽の場と しての重要な役割を担っている主1)。また、東京の多様な飲食店群は、 外国人観光客誘致の上でも世界で類をみない成熟した食文化の資源 として捉えられつつあり、2013 年に策定された「東京都観光産業振 興プランー世界の観光ブランド都市・東京をめざしてー」では、観光 産業振興に向けた施策展開の戦略の一つとして、アニメやファッショ ンに並び食文化の活用が強調されている ${ }^{3)}$ 。

こうした取り組みが進むなか、近年の都市部の飲食店は、新たな 局面を迎えている。すなわち、庶民志向と高級・グルメ志向の対比 のような単一な価值観に基づくものではなく、食の提供者・受容者 双方にとって、多様な食の経験注 2) の魅力が重要視されるようになっ ているのである注3)。そのため、今後も東京の食文化を発信・活用し ていく上で、食事内容のみならず雾囲気やサービス、コンセプト、 周辺環境などを含めた食の経験の魅力の重要度は益々高まっていく ものと考えられ、そうした観点から食事環境の魅力や地域性を論じ
ることが必要である。しかしこうした食の経験の質の議論やそれら の地理的特性に関する研究は、これまでほとんど行われてこなかっ た。

以上の背景から、都市における食の経験の実態及びその地域特性 を飲食店の分布傾向とともに明らかにすることは、豊かな東京の食 文化の利活用に向けて極めて重要かつ示唆を与えるものと考えられ る。

\section{1-2 研究の目的}

本研究では、都市に集積した多様な食の実態を把握するために、 東京都区部を対象に、飲食店の分布傾向や各地域での食事やサービ ス・店内空間等に関する価值表現（総じて「食の経験」の表現と呼ぶ） の地域特性を明らかにすることを目的とする。具体的には、以下 2 点を明らかにする。

1）業種別集積傾向からみる都内飲食店立地の地理的分布傾向 (3 章)

2) 都内で享受できる食の経験の体系と駅圈による差異 (4 章)

\section{1-3 研究の方法}

2 章では、まず東京における戦後の外食の歴史を既往文献などに よって整理し、現在の食事環境の位置づけを得る。3 章では、東京 都区部を対象にiタウンページを用いて飲食店の地理的分布特性を 明らかにし、特徵的な駅圈注 4) の抽出を行う。4 章では、食の情報に
*1 早稲田大学大学院創造理工学研究科建築学専攻 修士課程

$* 2$ 早稲田大学理工学術院 教授. 工博

*3 日本学術振興会 特別研究員 / 早稲田大学 博士後期課程
Grad. Student, Graduate School of Creative Sci. \& Eng., Waseda Univ. Prof., Faculty of Creative Sci. \& Eng., Waseda Univ., Dr.Eng. JSPS Fellow/Grad. Student, Dept. of Creative Sci. \& Eng., Waseda Univ., M.Arch. 
特化した飲食店情報サイトを用いて飲食店の売り文句の抽出を行い, 食事やサービス・店内空間等に関する価値表現（「食の経験」と呼ぶ） の全体構成を把握したのち、食の経験に基づいた各駅圈の特性を明 らかにする。 5 章では、飲食店立地と食の経験の地域特性について総 括する。

\section{1-4 研究の位置づけ}

我が国における都市の食文化及び食の経験に関する研究は、様々 な分野で分散的に行われてきた。岡田ら ${ }^{5)}$ は、都市観光の観点から 東京の各地域の飲食店の全体的な傾向とガイドブックへの掲載との 関係を明らかにしている。李 ${ }^{6)}$ は、下北沢を対象に各飲食店の分布 傾向と都市の回遊性及び集客性について論じている。小林 ${ }^{7)}$ は、飲

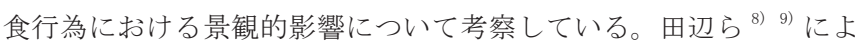
る一連の研究は、食の満足感の構成要素の因子を明らかにし、生理 的快適性のみならず精神的な快適性に関わる要因が重要な役割を 担っていることを明らかにしている。渡辺ら ${ }^{10)}$ の研究では、食情報 が食行動・意識に影響を与えることを明らかにしている。桂ら ${ }^{11)}$ の 研究では、北京市内 4 地区の住民を対象に大都市における外食行動 の分析を行っており、量的増大から質的多様化へ向から傾向を明ら かにした。

本研究は上記の研究の問題意識の延長にありながら、東京都区部 全域という規模で、初めて飲食店を悉皆的かつ即地的に捉える研究 である。加えて、食の情報を扱うウェブサイトを対象として「食の 経験」の質的な分析を行う点において独自性を有する。

\section{2 章＼cjkstart東京における食事環境の戦後史}

本章では東京における食事環境の戦後史を、特に外食の環境がど のように変わっていったのかに着眼し、文献調査により把握する。 戦後の食事環境の歴史についてまとめている本として、『近現代の食 文化』 ${ }^{12)}$ 、『日本食生活史年表』 ${ }^{13)}$ 、『平成食文化史年表』 ${ }^{14)}$ 、『日本 の食文化一その伝承と食の教育』 ${ }^{15)}$ を整理した。その結果、東京の 食事環境の戦後史は以下の 3 段階に分けられた。

\section{2-1＼cjkstart飲食業の戦後復興（1945～1955）}

戦後の日本の都市部では食糧不足が深刻であり、餓死者が続出し ていた主5)。これを受けて 1947 年には、主要食糧等のや夕取引を防止 し、その有効な活用を促進するため、飲食営業の合理的な規整を行 うことを目的とする飲食営業緊急措置令が制定された注6)。しかし実 態としては新宿の焼け跡に闇市が誕生し、盛り場を中心に広がって 人々の食生活を支えていた注7)。その後復興が進み、1955 年に米の生 産量が戦前の水準に回復した ${ }^{8)}$ 。そして、この頃から国際化・技術 革新・流通革命が始動し、日本人の食生活が大きく変化し、飢えか ら解放され、食事を楽しむことができるようになった注9)。

\section{2-2 外食の日常化・娛楽化 $(1956 \sim 1990)$}

1956 年までには深夜喫茶が急増しており、都が取締条例を公布施 行するまでになった ${ }^{\text {i住。1 }} 1960$ 年代半ばから都市部を中心にファース トフードのチェーン店が展開し始め、1969 年の第 2 次資本自由化に よる飲食業の $100 \%$ 自由化は、こうした傾向にさらに拍車をかけた注

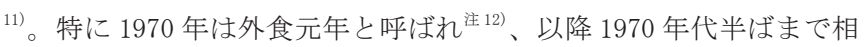
次いでファーストフード店やファミリーレストランが出店した ${ }^{\text {ì } 13)}$ それにより、特別な日の食事であった外食は日常的に楽しめるもの

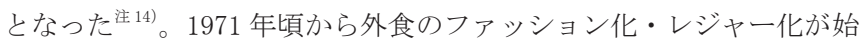

まっている ${ }^{\text {注 15) }}$ 。1960-70 年代を通じて家計の飲食料費に占める外食 費の割合も上昇している注16)。1980 年代半ばには「一億総グルメ」と 呼ばれるグルメブームが訪れる注 17 。都市部の料理店の国際色が豊か になり、エスニック料理など様々な食の流行が起こった注18)。

\section{2-3 食文化としての多様な外食 (1991 ～現在 $)$}

バブル経済の崩壊や環境問題の顕在化、食品偽装事件に対寸る不 安の拡大、健康志向の影響を受け、単純に「おいしい、高級な食材、 珍味」ではなく、地産地消や食育を大切にする「賢く食べること」 が見直されるようになった ${ }^{\text {注 }}$ 。同時に利用者にいかに気持ち良く過 ごしてもらえるか、いわば食事そのものではなく「食の経験」全体 が重視されるようになっている ${ }^{\text {注 } 20)}$ 。同時期には、飲食店の情報を扱 うウェブサイトが開設された ${ }^{21)}$ 。そして 2013 年に「東京都観光産 業振興プランー世界の観光ブランド都市・東京を目指してー」が策定 されて以来、東京の多様な飲食店を食文化という資源として活用し ていく方法が探られている注22)。

\section{3 章 業種別集積傾向からみる都内飲食店立地の地理的分布傾向}

本章では、東京都区部を対象として駅圈ごとの飲食店の集積傾向 を明らかにする。まず東京都区部の全飲食店の地理的分布特性を把 握し、その上で飲食店集積駅圈における立地業種の充実性と、駅の 乗降客数の関係から、集積傾向の分類を行う。

\section{3-1＼cjkstart業種別にみる飲食店の地理的分布特性}

まず、i タウンページ注23) に記載されている東京都区部の全飲食店 注 24) を業種 ${ }^{225}$ 別（「1. 居酒屋」「2. イタリアン・フレンチ」「3. 各 国料理」「4. カフェ」「5. カレー」「6. 郷土料理」「7. 魚料理」「8. ス イーツ」「9. すし」「10. そば・うどん」「11. たこ焼き・お好み焼き」 「12. 中華・ 中国料理」「13. 肉料理」「14. 飲み屋」「15. ファーストフー ド」「16. 弁当・宅配」「17. ラーメン」「18.レストラン注26)」「19. 和

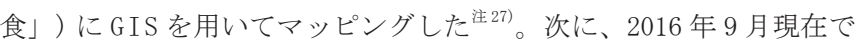
営業しているすべての駅の重心点注28) を基準にボロノイ図を作成し、

Table1 Correlation coefficient among 19 types

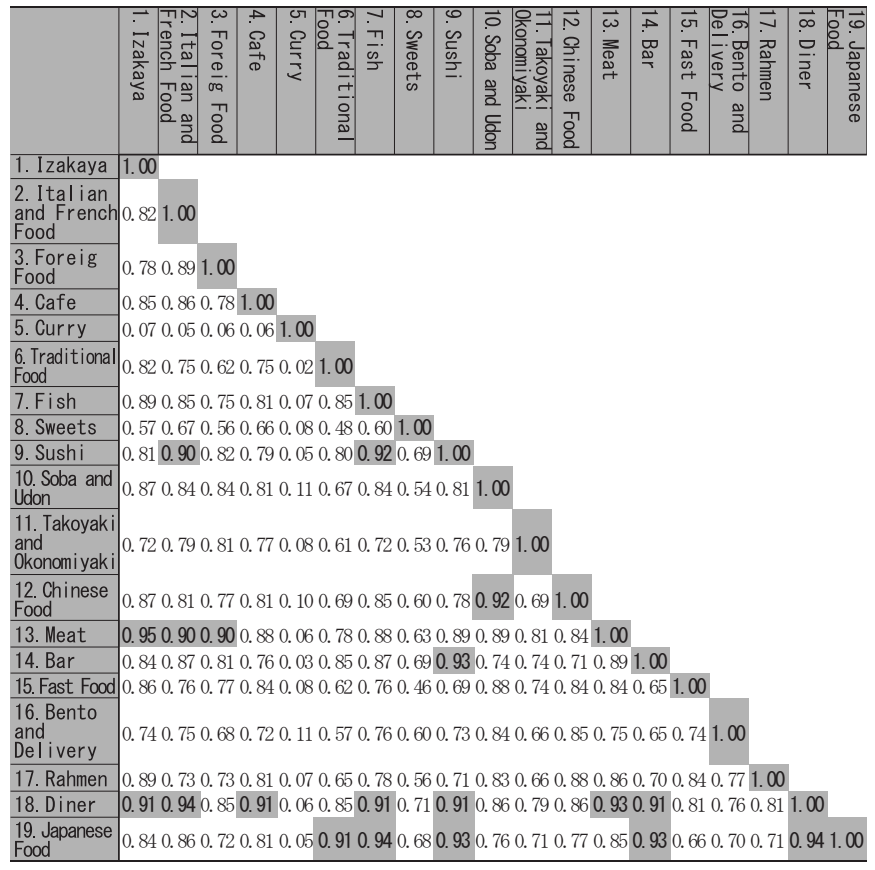




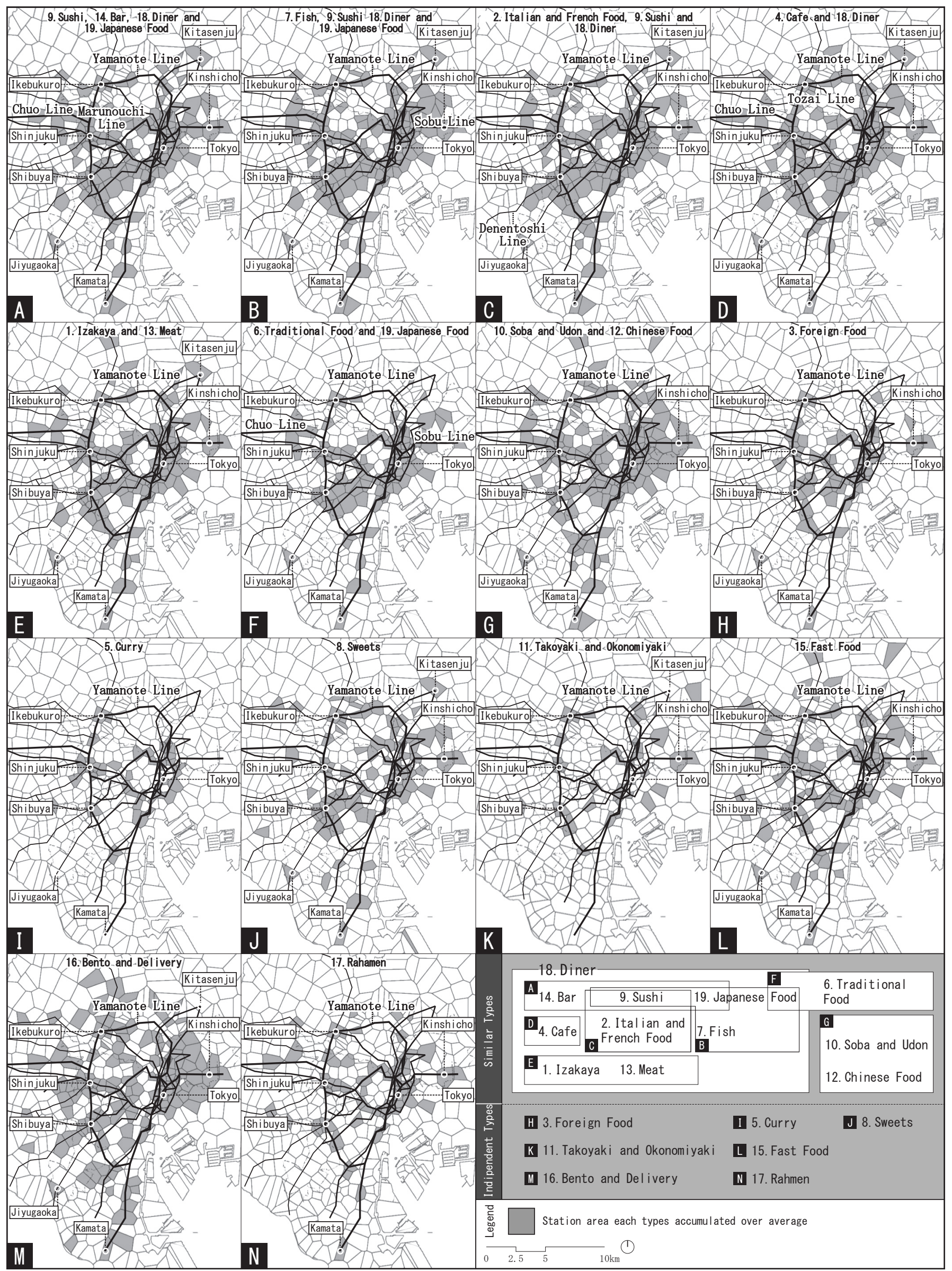

Fig. 1 Geographical distribution of restaurants depending on types 


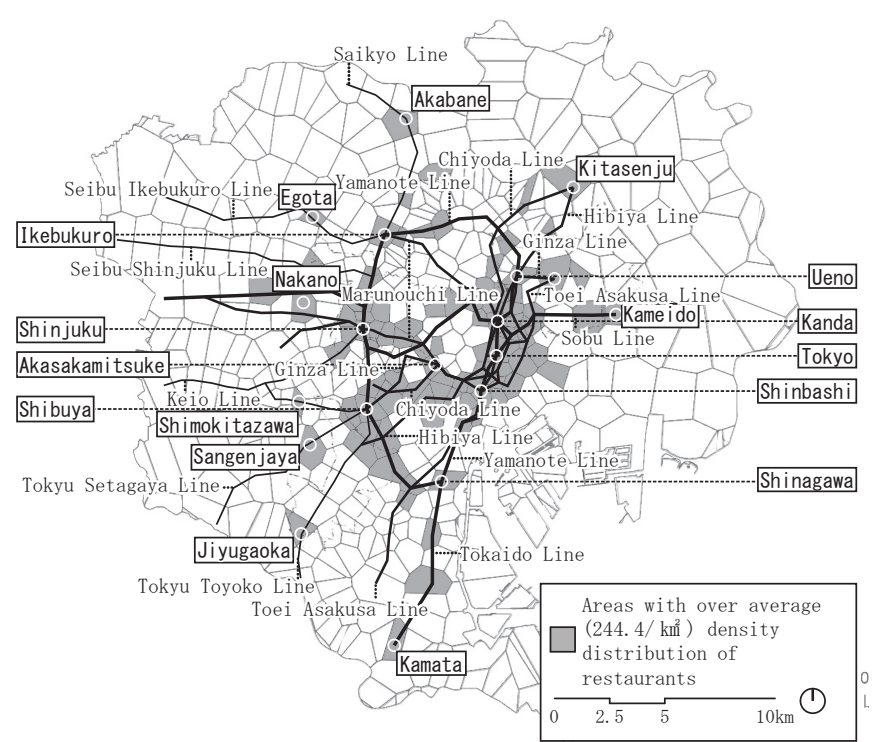

Fig. 2 Geographical distribution of station areas with restaurants accumulation

これらの多角形それぞれを各駅の「駅圈注 29) 」とした。そして、業種 別に各駅圈の単位面積当たりの飲食店数 (以下分布密度、単位：件 $/ \mathrm{km}^{2}$ ) を求めた。

以上の数值を用いて業種別の集積傾向を把握する。まず、各駅圈 での 19 業種間の分布密度の相関係数を求める ( T a b l e1、前々頁)。 この方法では、相関の高いものほど、同じ駅圏で密度の高い業種ど うしであるといえる。そこで、相関の高い（相関係数 0.90 以上）業 種どうしをまとめ、それぞれの業種について分布密度が平均以上の 駅圏を可視化した (Fig. 1、前頁)。

相関の高い業種は、それぞれ「レストランと相関が高い業種（更 にその中でA. -E. に分節される)」、「F. 郷土料理 / 和食」、「G. そば・ うどん/中華・中国料理」である。また、これら以外は「その他 (H. -N. )」 とした。「レストランと相関が高い業種 (A. -E. )」は全体的に山手線 の駅圈や郊外に向から路線の駅圈、更に東京周辺から渋谷周辺にか けて北東から南西に帯状に集積する傾向がある。また、「A. すし/飲 み屋/レストラン/和食」は特に丸の内線・中央線の西部に集積す る傾向がある。「B. 魚料理/すし/レストラン/和食」は特に総武線 以北に面的に集積する傾向がある。「C. イタリアン・フレンチ/すし /レストラン」は特に田園都市線沿いに集積する傾向がある。「D．カ フェ/レストラン」は特に中央線西部と東西線に集積する傾向がある。 「E. 居酒屋 / 肉料理」は A. - F. と比較すると、都区部南部や山手線内 側への集積が少なく、やや路線上に線的に集積する傾向がある。「 $\mathrm{F}$. 鄉 土料理 / 和食」は「レストランと相関が高い業種 (A. - E. )」と比較す るとやや集積している駅圏の数が少なく、都区部の中央・総武線以 南に集積する傾向がある。「G. そば・うどん/ 中華・中国料理」は特 に山手線の以東に面的に集積するほか、大崎駅周辺、及び都区部か ら郊外一向かう路線にも集積する傾向がある。

\section{3-2 飲食店集積駅圏の地理的分布特性}

前節では、業種別に集積駅圈の分布特性を把握した。本節では、 飲食店全体の集積傾向を明らかにする。

前節と同様、i タウンページに記載されている東京都区部の全飲食 店を、GIS を用いてマッピングし、駅圈ごとの分布密度と全体の平均

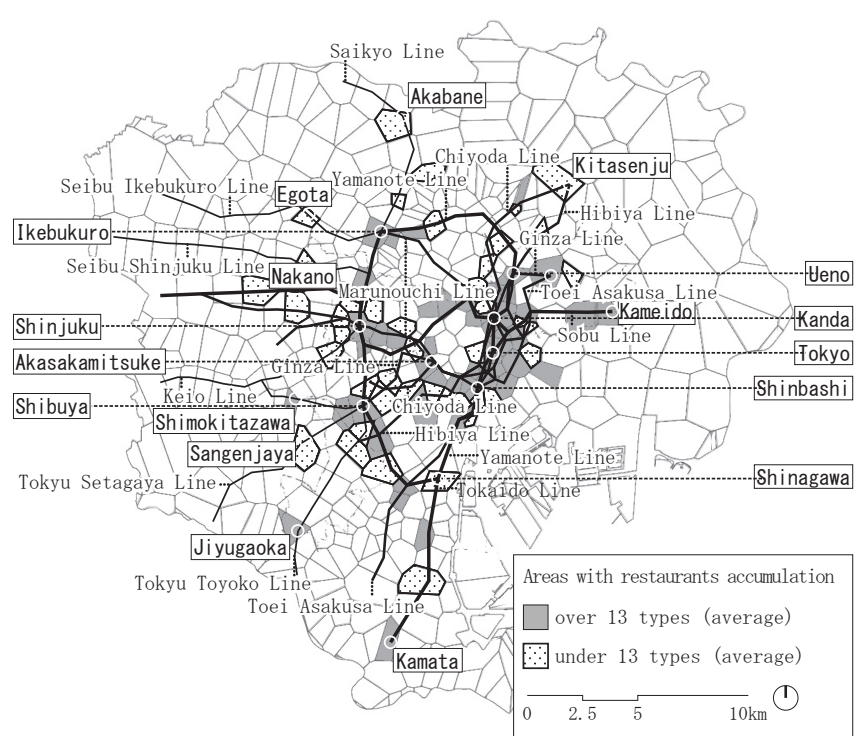

Fig. 3 Areas with plural restaurants accumulation

密度を求め、平均以上の駅圈を着色し、密度の高い地域の可視化を 行った (Fig. 2)。

都心部では、山手線・丸ノ内線・銀座線・千代田線・中央線・総武線・ 都営浅草線沿線の地域一の集積が大きい。特に都心東部は山手線に 沿って複数の路線が並走しており、その各駅圈に飲食店が集積する ため、帯状に集積地が広がっている。また、都心と 23 区外を結ぶ路 線のいくつかの駅圏にも集積しているが、これらの駅圏は同路線の 他の駅よりも利用者が多いものであると推察される。

これらより、東京都区部における飲食店は「(1)都心東部の複数の 路線が並走する地域」、「(2)新宿に隣接する地域と都心東部を結ぶ路 線上」、「(3)渋谷に隣接する地域と都心東部を結ぶ路線上」、「(4)池袋 に隣接する地域」「(5)都心と 23 区外を結ぶ路線の途中駅」の 5 地域 への集積がみられた。

\section{3-3 飲食店集積駅圏における充実業種数}

次に、それぞれの駅圈でどの程度多様な業種の飲食店が充実して いるかを「充実業種数」を算出することによって把握する。その際、 業種別にみた該当駅圈の店舗の分布密度が平均以上であることを、 対象地域において「充実している」と定義する。

駅圈における各業種の分布密度の特化係数を用いて、充実業種数 は次の計算式で与えられる。

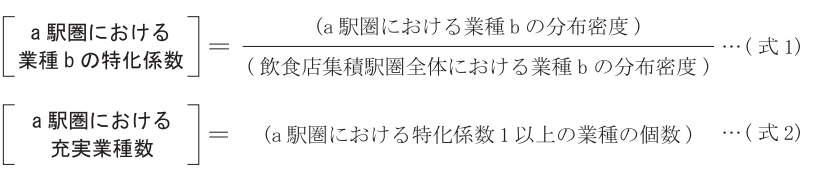

更に、すべての駅圏の充実業種数の平均を求めると、13 業種であっ た。平均以上の駅圈を着色し、多業種が充実する駅圈の可視化を行っ た (Fig. 3)。

都心東部の集積地では、各駅圈に多業種が充実するが、新宿・渋 谷に隣接する地域では、新宿駅圈・渋谷駅圈のみで多業種が充実し、 隣接駅圈には単業種が充実している。また、都区部の北西部の集積 地も単業種が充実している。

\section{3-4 立地業種の充実性と乗降客数に基づく飲食店集積駅圏の分類}

集積駅圈の特性を評価するため、「充実業種数」を縦軸、「駅の乗 


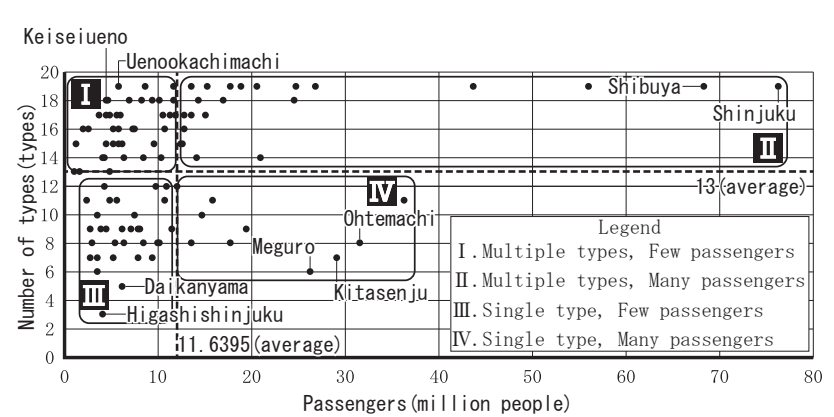

Fig. 4 Stations classification based on the number of the types of restaurants accumulation and passengers

Table2 Distinctive station areas

\begin{tabular}{l|l}
\hline \multicolumn{1}{c|}{ Accumulation tendency } & \multicolumn{1}{c}{ Disctinctive areas } \\
\hline I. Multiple types, Few passengers & Keiseiueno Uenookachimachi \\
\hline II. Multiple types, Many passengers & Shinjuku Shibuya \\
\hline III. Single type, Few passengers & Higashishinjuku Daikanyama \\
\hline IV. Single type, Many passengers & Kitasenju Ohtemachi Meguro \\
\hline
\end{tabular}

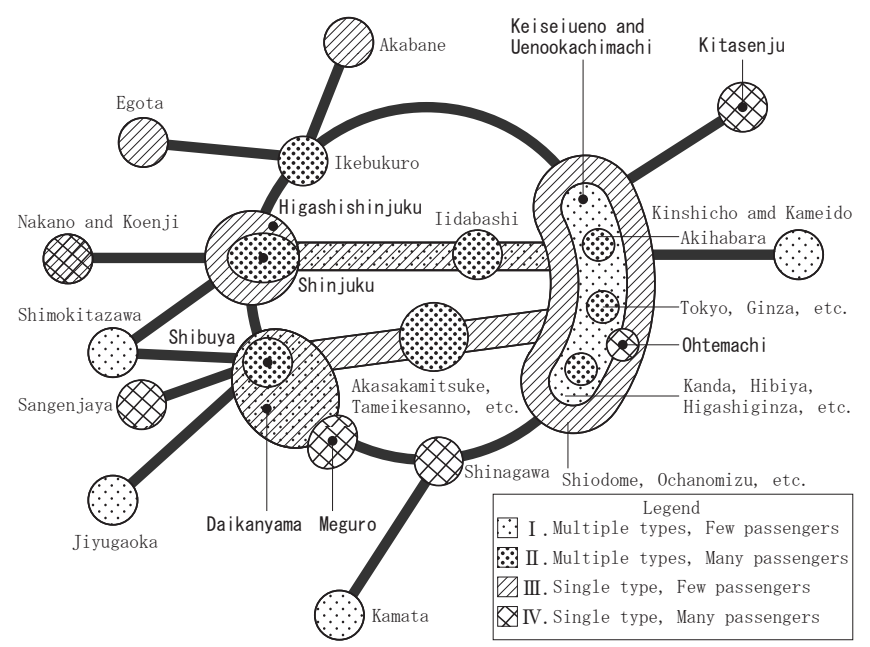

Fig. 5 Tendency of restaurants accumulation area (summery)

降客数」を横軸に据えて散布図を作成した (Fig. 4)。

乗降客数と充実業種数の平均をとり、これを基準に駅圈を「I . 多 業種・少乗降客」、「II . 多業種・多乗降客」、「III . 単業種・少乗降客」、 $\lceil I V$. 単業種・多乗降客」に分類した。乗降客数が 40 万人を超てい るものはすべて「多業種・多乗降客」に属することがわかる。また、 各分類においてその傾向が強いものを抽出し、T a b le2 に示した。次 章以降では、これら 9 つの駅圏の飲食店を対象に、食の経験の構造 を明らかにする。

\section{3-5 小結：飲食店集積駅圏の地理的分布の傾向}

これまでの分析結果を模式的にあらわすと、Fig. 5 が得られる。本 章では特徽的な飲食店集積を示寸地域として、5つの地域が得られた。

\section{1）都心東部の複数の路線が並走する地域}

「多業種・多乗降客」に属する山手線の駅圈及び銀座・茅場町の周 りに「多業種・少乗降客」の駅圏が集まる。

\section{2) 新宿に隣接する地域と都心東部を結ぶ路線沿い}

新宿は北部と西部を「単業種・少乗降客」の駅圈に囲まれているが、 東部に向かう路線の駅圈は「多業種・少乗降客」「単業種・少乗降客」
に属する。

\section{3）渋谷に隣接する地域と都心東部を結ぶ路線沿い}

東部一向かう路線の駅圈の多くが「単業種・少乗降客」に属する。 渋谷駅に隣接する駅圈は「多業種・少乗降客」「単業種・少乗降客」 に属する。

\section{4）池袋に隣接する地域}

池袋のみが「多業種・多乗降客」に属している。

\section{5）都心と 23 区外を結ぶ路線の途中駅}

中央・総武線以北/以南で傾向が異なる。以北では「単業種・少 乗降客」が多いが、以南では「多業種・少乗降客」に属する駅圈が みられる。

以上の分析から、東京都区部内でも駅圈や路線ごとに飲食店の集 積傾向が異なるということが確認できる。

\section{4 章＼cjkstart都内で享受できる食の経験の体系と駅圏による差異}

前章にて充実業種数と乗降客数に基づいて駅圈を分類した。本章 では、各分類の傾向を顕著に表している 9 つの駅圈を対象に、それ ぞれにおいて享受できるとされる「食の経験」の差異や地域による 特性を明らかにする。具体的には、9つの駅圈の飲食店を対象に、飲 食店を網羅的に扱っている最大規模のウェブサイトの一つである「ぐ るなび」に掲載されている売り文句注 ${ }^{30}$ に表れる価值表現を採集し 「食の経験」の語りとして扱い、その抽出・類型化を行う。その上で、 食の経験からみる駅圏の地域特性を明らかにする。

\section{4-1 駅圏内の飲食店の抽出及び食の経験の抽出と分類}

\section{1) 食の経験の記載のある飲食店の抽出}

まず、iタウンページに掲載されている全飲食店を、GIS を用いて プロットし、ボロノイ図を重祆合わせることで、各図形（すなわち 駅圈 ）に立地する飲食店を抽出する。次に抽出された飲食店ひとつ ひとつを検索し、「ぐるなび」に掲載されているものを選出する。こ の分析方法の限界から、以下の方法で食の経験の表現のある店舗の 抽出を行った。

まず、各駅圈に立地している飲 Table3 Number of restaurants 食店を抽出する。次に、抽出した with the expression of eating 飲食店を無作為に選び、「ぐるなび」 で検索し、食の経験の表現を抽出 する。このとき、食の経験の表現 のある店舗の抽出は各駅ごとに最 大で 100 件までとする。ただし、 抽出された飲食店には食の経験の 表現が存在しないものもある。そ のため、分析対象となる店舗数が 100 件を下回る駅圈が存在する。

\begin{tabular}{|c|c|c|c|}
\hline \multicolumn{2}{|r|}{ Station areas } & \begin{tabular}{|l|} 
number of \\
extr acted \\
restaurants
\end{tabular} & \begin{tabular}{|l} 
number of \\
appropriate \\
restaurants
\end{tabular} \\
\hline \multirow{2}{*}{ I } & Keiseiueno & 295 & 57 \\
\hline & Uenookachimachi & 367 & 47 \\
\hline \multirow{2}{*}{ II . } & Shinjuku & 739 & 100 \\
\hline & Shibuya & 1801 & 100 \\
\hline \multirow{2}{*}{ III } & Higashishinjuku & 187 & 20 \\
\hline & Daikanyama & 220 & 31 \\
\hline \multirow{3}{*}{ IV. } & Kitasenju & 605 & 68 \\
\hline & Ohtemachi & 154 & 65 \\
\hline & Meguro & 431 & 72 \\
\hline
\end{tabular}

以上の方法で最終的に対象となった飲食店数を Table3 に示す。

\section{2）食の経験の抽出と分類}

対象となった店舗情報のうち、食事の内容、食事を行う空間、様々 なサービスやイベント、周辺地域の売り文句を採集し、「食の経験」 についての語りとみなした。

採集された食の経験についての語り 2248 サンプルを、KJ 法を参照 して意味の同一視できるものに分類した。分類結果は「食事内容 $(32$ 分類、1182 サンプル)」「食事空間 (26 分類、503 サンプル)」「空間 
Table4 List of extracted eating experiences
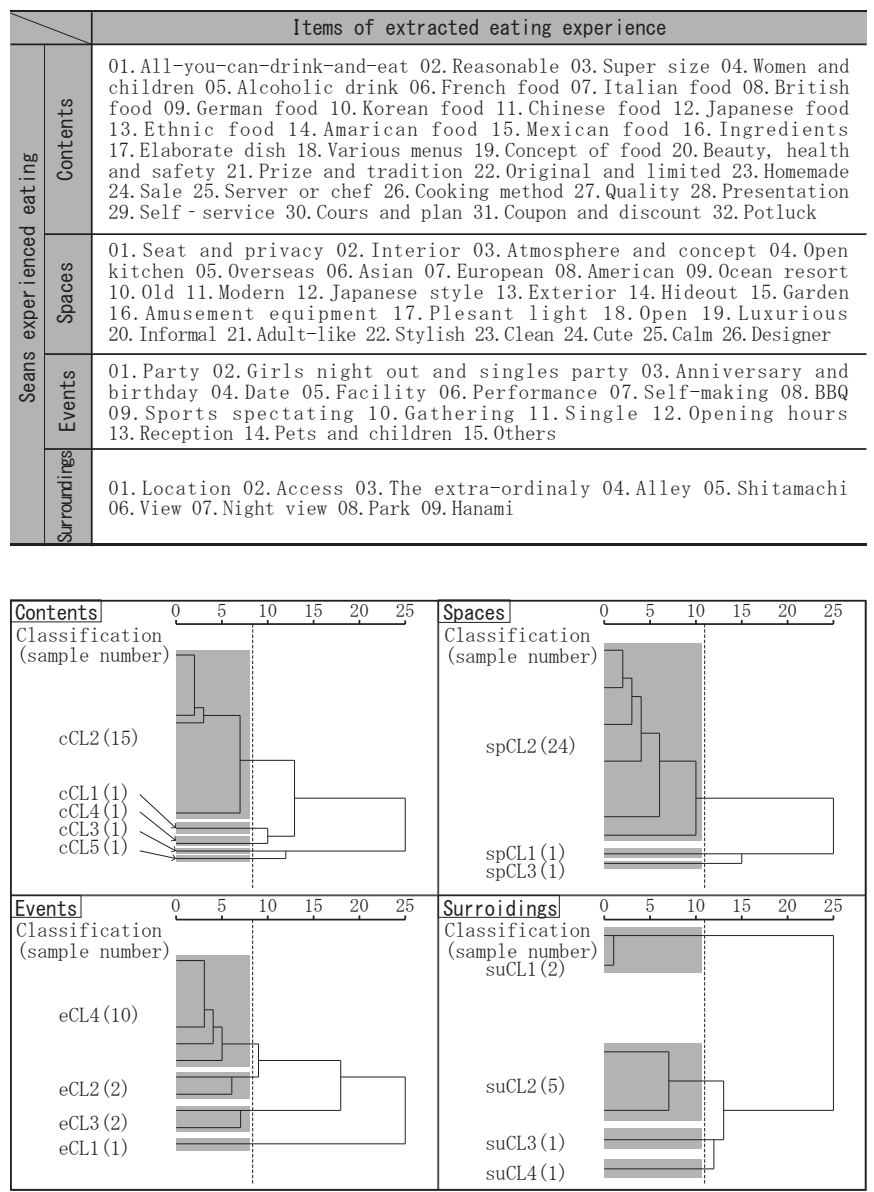

Fig. 6 Classification of extracted eating experience

内の出来事 (15 分類、464 サンプル)」「周辺地域 (9 分類、99 サンプ ル)」に整理された (Table4)。

\section{4-2 食の経験の類型化}

食の経験の分類 (食事内容 32、食事空間 26、空間内の出来事 15 、 周辺地域 9）を更に似通ったものどうしで類型化する。食の経験の 各項目の該当の有無をパラメータ化し、これを用いて店舗について ウォード法によるクラスタ分析 (ユークリッド距離)を行った。ク ラスタの数が極端に大きくなる手前でデンドログラムを切断し、

Fig. 6 のクラスタを得た。

\section{1）食事内容の類型}

食事内容のクラスタの構成要素を示したのが Table5 である。表中

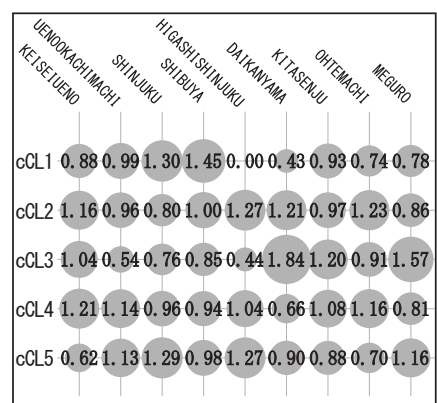

Fig. 7 Specialization coefficient of contents in each station areas

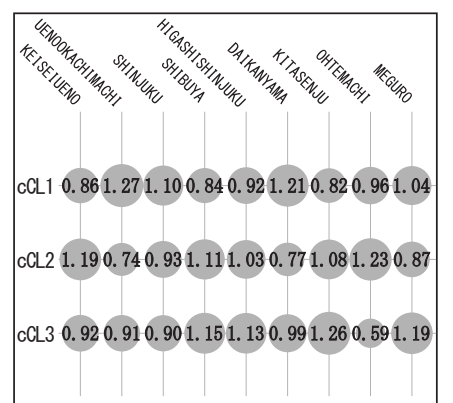

Fig. 8 Specialization coefficient of spaces in each station areas

Table5 Classification of experience of "contents"

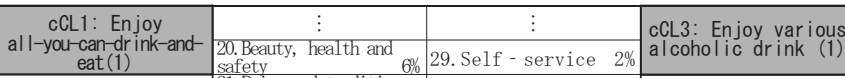

01. all-yourcandrink-and eat 21 . Prize and tradition $\%$ 19. Concept of food 1\% 05 . Alcoholic drink $100 \%$ 3. Super size $\quad 4 \% 10$. Korean food $1 \%$

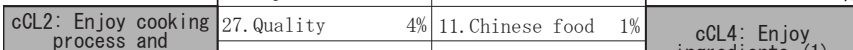

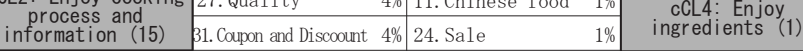

26. Cooking method 14\% 18 . Various menus $3 \%$ 09. German food $1 \%$ 16. Ingredients $100 \%$

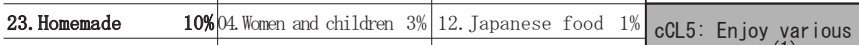
30. Course and plan $9 \% 28$. Presentation $3 \%$ 15. Mexican food $1 \%$ menus (1) 25. Server or chef $7 \% 06$. French food $\quad 2 \%$ 32. Potluck $\quad 1 \% 17$. Elaborate dish $100 \%$ 22. Original and limited $7 \%$ 07. Italian food $2 \% 08$. British food $1 \%$ \begin{tabular}{lll|l}
\hline 02. Reasonable & $6 \%$ 13. Ethnic food & $2 \%$ & 14. Amarican food $1 \%$ \\
\hline
\end{tabular}

Table6 Classification of experience of "spaces"

\begin{tabular}{|c|c|c|c|c|c|c|c|}
\hline \multirow{2}{*}{\multicolumn{2}{|c|}{$\begin{array}{l}\text { spCL1: Space valued } \\
\text { seat and privacy (1 }\end{array}$}} & & & & \\
\hline & & 22. Stylish & & 21. Adult-like & $3 \%$ & 23. Clean & $1 \%$ \\
\hline 1. Seat and privacy & $100 \%$ & 17. Plesant light & & 06. Asian & $3 \%$ & 26. Designer & \\
\hline \multirow{2}{*}{\multicolumn{2}{|c|}{$\begin{array}{l}\text { spCL2: Space valued } \\
\text { facilities (24) }\end{array}$}} & 04. Open kitchen & & $10.01 \mathrm{~d}$ & $3 \%$ & 05. Overseas & $1 \%$ \\
\hline & & \multirow{2}{*}{$\begin{array}{l}\text { 03. atmosphere and } \\
\text { concept }\end{array}$} & & 15. Garden & $3 \%$ & 24. Cute & $1 \%$ \\
\hline Open & $15 \%$ & & & 19. Lux & $9 \%$ & 08. Amer & $0.4 \%$ \\
\hline & $14 \%$ & 14. Hideout & 5 & & $2 \%$ & 20. Informa1 & $0.4 \%$ \\
\hline Exterior & $8 \%$ & & & 07. European & $2 \%$ & spCL3: Space 0 & $\operatorname{lm}(1)$ \\
\hline & & & & & & & \\
\hline
\end{tabular}

Table7 Classification of experience of "events"

\begin{tabular}{|c|c|c|c|c|c|}
\hline \multirow{2}{*}{$\begin{array}{l}\text { eCL1: Enjoy party } \\
\text { (1) }\end{array}$} & \multirow{3}{*}{ 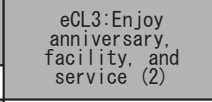 } & \multirow{2}{*}{\multicolumn{2}{|c|}{$\begin{array}{c}\text { eCL4: En joy } \\
\text { reception and } \\
\text { performance (10) }\end{array}$}} & \multirow{2}{*}{\multicolumn{2}{|c|}{\begin{tabular}{|c|} 
\\
12.0 pening hours $10 \%$ \\
\end{tabular}}} \\
\hline & & & & & \\
\hline 01. Party & & 06. Performance & $23 \%$ & 10. Gathering & \\
\hline \multirow{2}{*}{$\begin{array}{l}\text { eCL2: Enjoy girls } \\
\text { night out, singles } \\
\text { party and date (2) }\end{array}$} & 05. Facility & 6. 13. Reception & $15 \%$ & 15. Others & $6 \%$ \\
\hline & \multirow{2}{*}{$\begin{array}{l}\text { 03. anniversary and } \\
\text { birthday }\end{array}$} & \multicolumn{2}{|c|}{ 09. Sports spectating } & \multicolumn{2}{|c|}{ 14. Pets and children $3 \%$} \\
\hline \multirow{2}{*}{$\begin{array}{l}\text { 02. Girls night out } \\
\text { and singles party } 57 \%\end{array}$} & & & $14 \%$ & 08. BBQ & $2 \%$ \\
\hline & & 07. Self-making & $11 \%$ & & \\
\hline 4. Date & & 11. Single & $11 \%$ & & \\
\hline
\end{tabular}

Table8 Classification of experience of "surroudings"

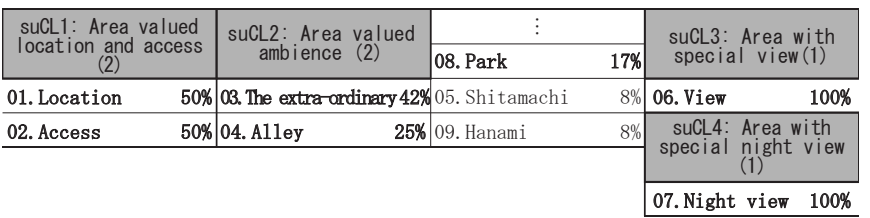

では食の経験の類型を構成する食事内容の中で該当項目が占める比 率を示している。このうち、高い比率を占めるものに基づいて各ク ラスタを命名したところ、名称は「CCL1：食べ放題・飲み放題享受」 $\lceil\mathrm{CCL} 2$ : 調理過程 - 食情報享受」「CCL3：多様な酒享受」「CCL4：食材享 受」「CCL5：多様なメニュー享受」と設定された。

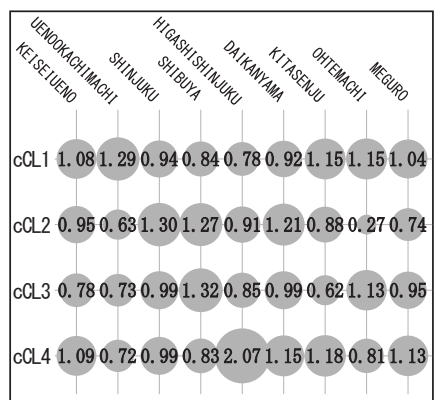

Fig. 9 Specialization coefficient of events in each station areas

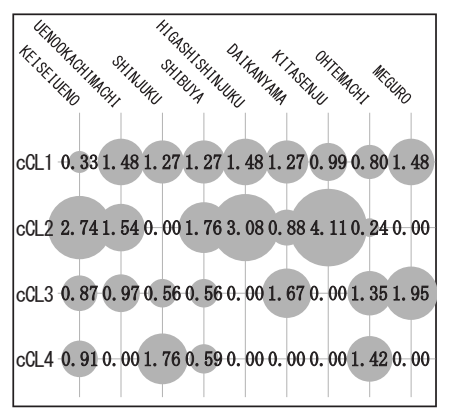

Fig. 10 Specialization coefficient of surroudings in each station areas 
更に、食事内容に基づいた各駅圈の特性を把握するために、各駅 園における各食事内容類型の特化係数注 ${ }^{31}$ を算出し、Fig. 7 (前頁) に示した。

東新宿と代官山はそれぞれ食事内容の独自性が高いと言える。し かし、その他の駅圈は極端に特化/非特化しているものはみられず、 充実業種数と乗降客数による分類内での類似性は確認できなかった。

\section{2) 食事空間の類型}

食事空間のクラスタの構成要素を示したのが Tab le6 (前頁) であ る。同椂に、高い比率を占めるものに基づいて各クラスタを命名し たところ、名称は「spCL1：席・プライベート重視空間」「spCL2：し つらえ重視空間」「spCL3：くつろぎ重視空間」と設定された。

更に、食事空間に基づいた各駅圈の特性を把握するために、各駅 園における各食事内容類型の特化係数を算出し、Fig. 8 (前頁) に示 した。

大手町の spCL3: くつろぎ重視空間が他の駅圈と比較してやや少な い傾向にある。しかし、その他のクラスタは駅圈による差異は小さい。 したがって、駅圈による食事空間の差異は小さいと言える。

\section{3）空間内の出来事の類型}

空間内の出来事のクラスタの構成要素を示したのが Table7 (前頁) である。同様に、高い比率を占めるものに基づいて各クラスタを命 名したところ、名称は「eCL1：宴会・パーティー満喫」「eCL2：女子会・ 合コン・デート満喫」「e CL3：記念日・設備・サービス満喫」「eCL4： 接客・パフォーマンス満喫」と設定された。

更に、空間内の出来事に基づいた各駅圈の特性を把握するために、 各駅園における各食事内容類型の特化係数を算出L、Fig. 9 (前頁) に示した。

東新宿が eCL4：接客・パフォーマンス満喫に大きく特化していこ とが分かる。また、大手町の eCL2：女子会・合コン・デート満喫の 特化係数が極端に小さいなど、充実業種数と乗降客数による分類内 での明確な類似性は確認できなかった。

\section{4）周辺地域の類型}

周辺地域のクラスタの構成要素を示したのが Tab le8 (前頁) であ る。同様に、高い比率を占めるものに基づいて各クラスタを命名し たところ、名称は「suCL1：立地・アクセス重視地域」「suCL2：周辺 環境重視地域」「suCL3：眺望格別地域」「suCL4：夜景格別地域」と設 定された。

更に、周辺地域に基づいた各駅圈の特性を把握するために、各駅 園における各食事内容類型の特化係数を算出L、Fig. 10 (前頁) に示 した。

周辺地域の経験は駅圈による差異が大きい。特に suCL2：周辺環境 重視地域は駅圏により特化 / 非特化の度合いの差が大きい。また、 各クラスタの特化係数の值と充実業種数と乗降客数による分類内で の明確な類似性は確認できなかった。

\section{4-3＼cjkstart駅圏ごとにみる食の経験の特性}

これまでに抽出した食の経験の駅圈ごとの比率を Fig. 11 (次頁) に示した。

3 章において、充実業種数と駅の乗降客数から駅圈の分類を行った が、これに基づいた分類内での類似性は確認されず、食の経験は駅 圈ごとに特性があることが明らかになった。共通する傾向として食 の経験全体の中では食事内容の割合が最も高くなるということが確

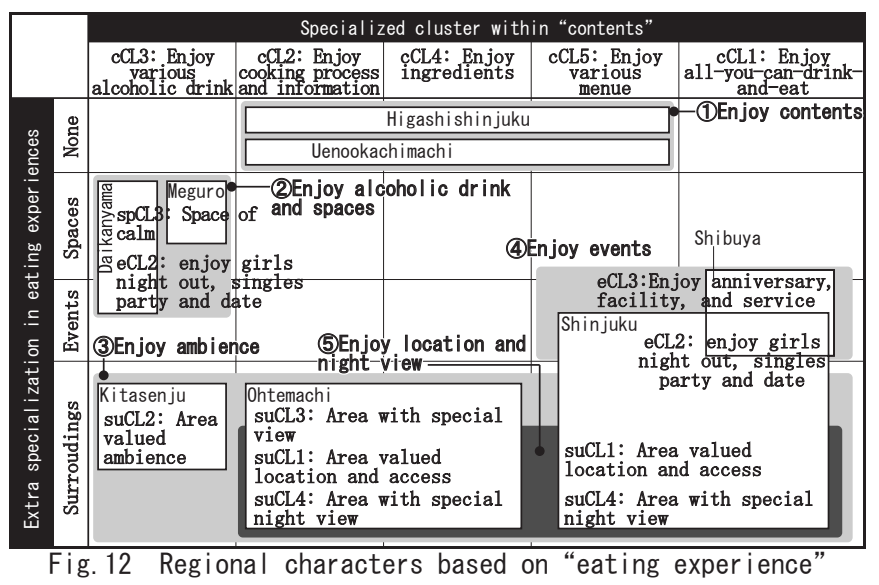

(summery)

認された。また、特に顕著な傾向がある駅圈として、渋谷・東新宿・ 代官山・大手町が挙げられる。渋谷は 9 駅圈のうち最も空間内の出 来事に関する経験が多く、他の駅圈と比較して eCL3：記念日・設備 · サービスの比率が大きい。東新宿は食事内容の経験に大きく偏って いる。代官山は 9 駅圏のうち唯一食事内容が 5 割を切り、食事空間 の経験の比率が大きい。大手町は全駅圈のうち最も周辺地域の比率 が大きく、特に suCL3：眺望格別地域、suCL4：夜景格別地域に偏って いる。

\section{4-4 小結：食の経験に基づく駅圏の分類}

これまでの分析結果より、各駅圈で享受できる食の経験に基づく 地域特性について、「食事内容に関する差異」と「食事内容以外の食 の経験のうち構成比が平均より高いもの」からまとめると Fig. 12 が 得られる。

食の経験に基づいた駅圈の地域特性は、いずれの食の経験にも特 化していなかった京成上野を除き、それぞれ、(1)食事内容享受（上 野御徒町・東新宿)、(2)酒・食事空間享受 (代官山・目黒)、(3)周辺 環境享受 (北千住・大手町・新宿)、(4)出来事享受 (新宿・渋谷)、 (5)立地・夜景享受 (大手町・新宿 ) となった。

\section{5 章 結語}

本稿では、飲食店の分布傾向や食の経験という観点から、東京都 区部における食事環境の実態や地域特性を明らかにしてきた。最後 に、本研究で得られた知見を以下にまとめる。

\section{5-1 研究のまとめ}

本研究では、東京都区部における飲食店立地の地理的分布傾向を 把握したのち、食事環境の地域特性を、各駅圏における、立地して いる飲食店の業種数の多さ (充実業種数) と乗降客数、次に食の経 験という観点から論じてきた。

まず、東京都区部における 19 業種の地理的分布傾向の相関につい て明らかにした上で、相関の高い業種の集積傾向について明らかに した。「レストランと相関が高い業種 (A. -E. )」は山手線のほか東京 周辺から渋谷周辺に帯状に集積し、「F. 郷土料理 / 和食」は都区部南 部に集積し、「G. そば・うどん/中華・中国料理」は都区部東部に集 積することがわかった。次に、飲食店が集積している駅圈を明らか にし、飲食店は「(1)都心東部の複数の路線が並走する地域」、「(2)新 宿に隣接する地域と都心東部を結ぶ路線上」、「(3)渋谷に隣接寸る地 


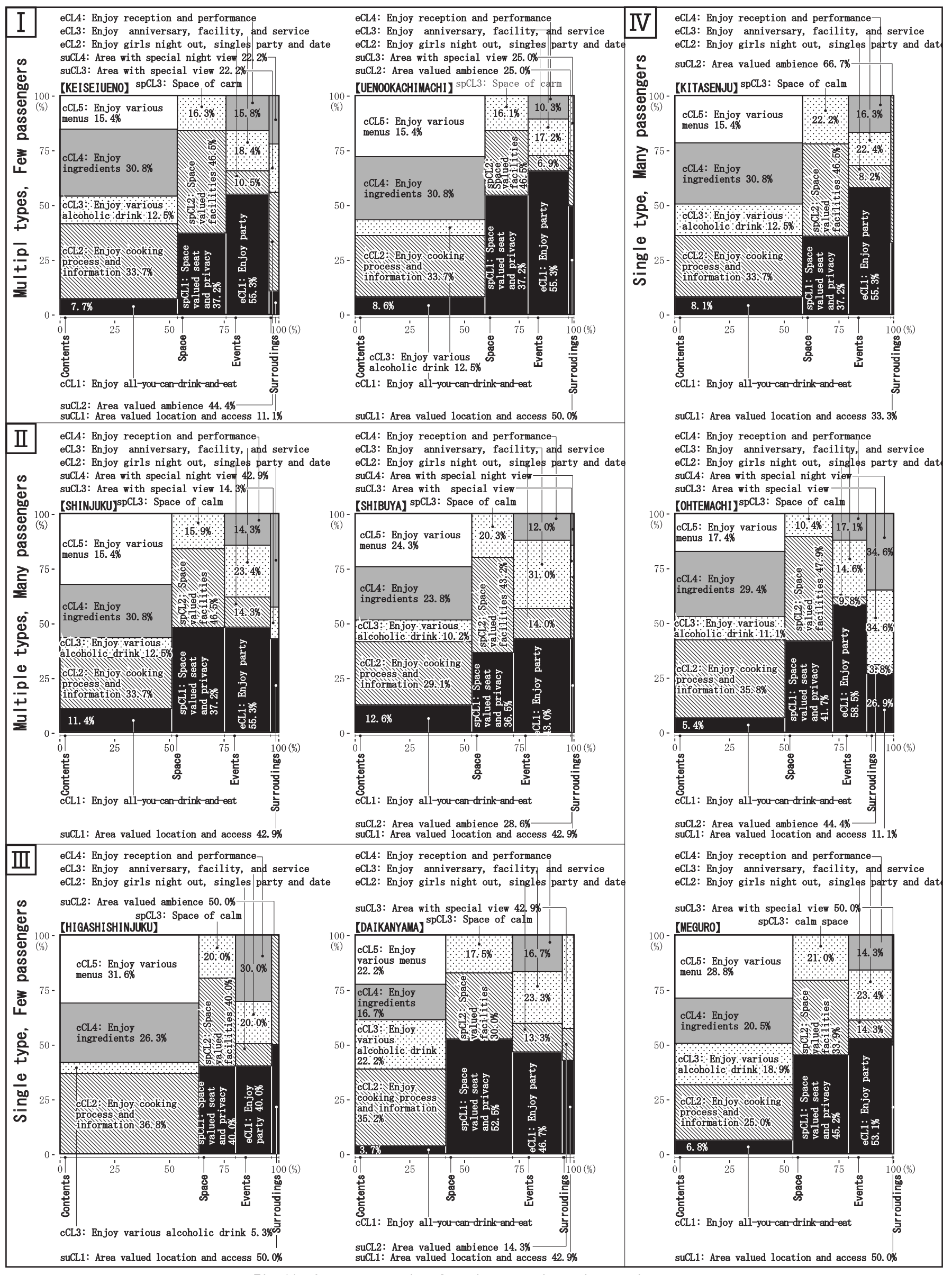

Fig. 11 Component ratio of eating experience by station area 
域と都心東部を結ぶ路線上」、「(4)池袋に隣接する地域」、「(5)都心と 23 区外を結ぶ路線の途中駅」の 5 地域一集積することがわかった。 また、各駅圈における充実業種数と乗降客数を求め、それらを指標 に飲食店が集積している駅圈の地域性を評価し、「多業種・少乗降客」、 「多業種・多乗降客」、「単業種・少乗降客」、「単業種・多乗降客」の 4 つの分類を得た。また、飲食店が集積する 5 地域それぞれの特徽に ついても明らかにした。

更に、各分類の傾向を顕著に表している駅圈をそれぞれ選び、選 ばれた $9 つ の$ 駅圈（京成上野・上野御徒町・新宿・渋谷・東新宿・ 代官山・北千住・大手町・目黒）について食の経験を抽出したのち、 食の経験に基づいた各分類や各駅圈の地域性及び差異を明らかにし た。その結果、都内で享受できるとされる食の経験は 82 種類抽出され、 それらは「食事内容」、「食事空間」、「空間内の出来事」「「周辺地域 の 4 つに分類できた。「食事内容」は東新宿・代官山が独自性が高く、 それ以外の駅圏については大きく特化 / 非特化しているものは見ら れなかった。「食事空間」は駅圈による差異は小さい。「空間内の出 来事」は東新宿と大手町以外は駅圏による差異は小さい。「周辺地域」 は駅圈による差異が最も大きい食の経験である。そして、これら 4 つの食の経験に基づいて駅圈の特性をみると、食事内容に関する差 異と食事内容以外に特化している食の経験に基づき (1)食事内容享受 ( 上野御徒町・東新宿 )、(2)酒・食事空間享受 (代官山・目黒)、(3) 周辺環境享受 (北千住・大手町・新宿 $) 、(4)$ 出来事享受 $($ 新宿・渋谷 )、 (5)立地・夜景享受 (大手町・新宿) といった異なる 5 つの地域特性 が指摘できた。これらは、充実業種数と乗降客数から把握できる地 域特性とは別に、「食の経験」から読み取れる特有の地域特性だと考 えられる。

\section{5-2 本研究の到達点と課題}

本研究を通して東京都区部における食事環境は、(1)食事内容享受、 (2)酒・食事空間享受、(3)周辺環境享受、(4)出来事享受、(5)立地・夜 景享受のように、享受できるとされる経験の内容に基づいた地域に よる特色があることが明らかになった。このことは、都市部におけ る食が高度な地域性を形成していることを示唆している。また、地 域ごとに独自の異なる経験ができるというのが東京都区部の食文化 の魅力の一つであるといえよう。更に、これらの地域性は業種別集 積傾向や乗降客数等の指標では把握しきれず、飲食店が提供する「食 の経験」という面からはじめて把握されるものである。

このように、東京の食文化を有効に活用・発信していくためには「食 の経験」がつくる地理空間に着目寸る新たな研究領域が必要である と考えられる。本研究ではその分析方法を提示し、いくつかの特徵 的な地域を対象に端緒となる成果を得ることができた。今後は、よ り多くの駅圈を対象とした東京都区部全域的な分析を行い、ある程 度のまとまりを持った外食文化圈を明らかにするような研究や、特 に建築・都市計画分野においては食事空間や周辺環境に関するより 詳細な研究が望まれる。

\section{注}

注 1）例えば、食文化研究の第一人者である石毛は「盛り場に高密度に集中し た飲食業は、家庭の日常の飲食では体験できない多様な選択を提供してきた。 味覚情報の集積された空間としての盛り場は、食事文化センターとしての都 市のショーウィンドーである。と論じている (参考文献 2)）。

注 2) 後述するように、本稿では「飲食店において享受できる食事内容・食事 空間・空間内の出来事・周辺地域の経験」を総じて「食の経験」と呼ぶ。

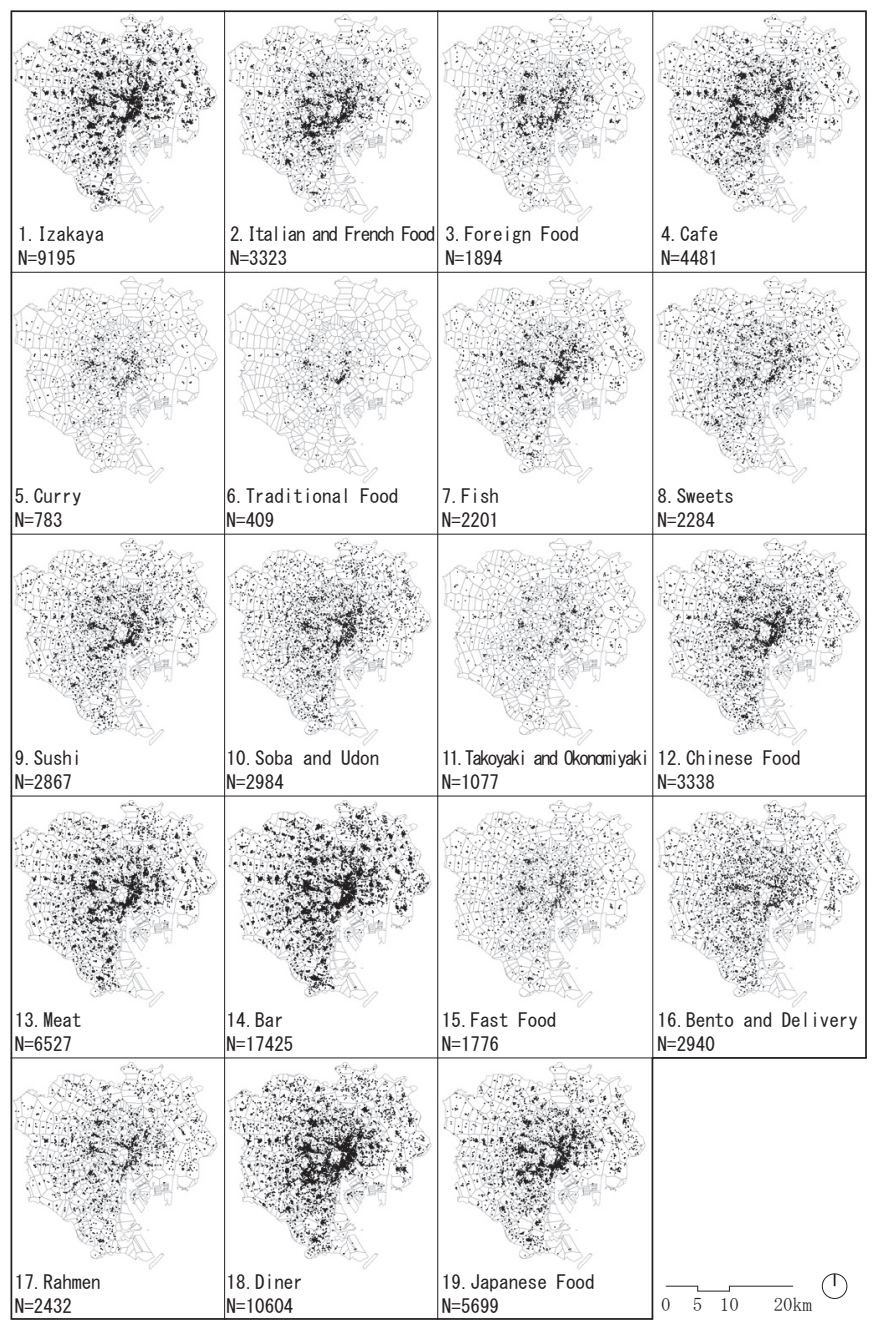

Attached Fig. Geographical Distribution of each restaurants

注 3）森孝郎は日本人の食の「質志向」への変化の特徵として「食味重視」、「健 康志向」、「ファッション性」、「文化性」の高まりの 4 点をあげている（参 考文献 4) )。

注 4）東京都区部は鉄道が輻輳しており、一般に、鉄道の旅客需要の予測を目 的に、駅を中心に徒歩到達が可能な距離（半径 $1.5-2 \mathrm{~km}$ ）に基づく「駅勢 圈」を設定することは困難であるため、本研究では「駅圈」を採用すること とした。駅の重心点 ${ }^{28}$ ） を基準にボロノイ図（空間上の任意の位置に配置さ れた複数個の点（母点）に対して、同一距離空間上の他の点がどの母点に近 いかによって領域分けされた図）を作成し、これらの多角形それぞれを各駅 の「駅圏注 29)」とした。

注 5) (参考文献 13) ), p. 156 を参照。

注 6) 衆議院「法律第五二号」〈http://www. shugiin. go. jp/internet/itdb_ housei.nsf/html/houritsu/00519490507052.htm〉，2014，（閲覧日 2016 年 8 月9日)

注 7) (参考文献 13))，p. 158 を参照。 注 8) (参考文献 12) ), p. 158 を参照。 注 9) (参考文献 12) ), p. 158 を参照 注 10) (参考文献 12)), p. 172 を参照。 注 11) (参考文献 12)), p. 169 を参照 注 12) (参考文献 15))，p. 138 を参照 注 13) (参考文献 12))，p. 169 を参照 注 14) (参考文献 15)), p. 139 を参照 注 15) (参考文献 13)), p. 188 を参照

注 16）公益財団法人食の安全・安心財団〈http://anan-zaidan. or. jp/data/〉, （閲覧日 2016 年 8 月 9 日 )

注 17) (参考文献 15)), p. 139 を参照

注 18) (参考文献 12))， p. 200 を参照。 注 19）（参考文献 15）），p. 139 を参照。 
注 20) (参考文献 15))，p. 139 を参照。

注 21) (参考文献 16)), p. 32 を参照。

注 22) (参考文献 3) ) を参照。

注 23）i タウンページとは、日本全国のお店・施設・会社等の住所や業種が検 索できるサイトである。なお、掲載されているデータは「 i タウンページに 掲載されている店舗・施設・会社の情報は「番号情報データベースシステ ム（TDIS）」をベースに i タウンページを運営するNTT タウンページ株式会 社が、独自に設定した業種名や収集したお店・施設・会社の詳細な情報を編 集して掲載しております。」とされている。（NTTタウンページ株式会社「へ ルプ i タウンページについて「i タウンページ」とは」<https://itp.

ne. jp/guide/web/manual/itp/about.html>) したがって、iタウンページ に掲載されている限りで駅ナカや駅ビル内の飲食店も含まれる。

注 24) 2016 年 7 月時点の i タウンページに掲載されているものとする。

注 25）ここでの業種は i タウンページで使用されているNTT 分類に基づくもの

とする。また、1つの店舗について複数の業種があげられる場合は重複集計 した。

注 26）英訳するにあたり、本稿では混同を防ぐため、「飲食店」を「restaurant」、

「NTT 分類におけるレストラン」を「diner」とした。

注 27）各業種の分布状況を付図（前頁）に示す。

注 28）国土交通省国土政策局国土情報課が整備している GIS データである国土

数值情報 鉄道データにおいて、ラインデータで提供される駅をポリゴンに

変換し、そのポリゴンの重心をとったものである。

注 29）東京都区部を対象にするにあたり、市部との境界は多角形の辺ではなく 行政境界とした。駅圏は計 479 個あり、面積の最小值は $0.00057 \mathrm{~km}^{2}$ 、中央値 は $0.99 \mathrm{~km}$ 、最大值は $8.11 \mathrm{~km} 2$ である。

注 30）本研究では「ぐるなび - レストラン予約と宴会・グルメ情報 検索サイ ト」, https://www. gnavi.co.jp/ におけるすべての店舗記事での共通項目 である「ピックアップ写真」の説明文を売り文句として抽出した。この項 目では、複数の写真とともに飲食店の売りとしている事項が端的に示されて いる(閲覧日 2016 年 10 月 10-14 日)。なお、売り文句の読み取りと「価值 表現」としての分析方法については、住宅広告の価值表現の分析を行った既 往研究 (参考文献 17) ) を参照している。

注 31) 特化係数は以下の計算式により求められる。

( $\mathrm{x}$ 駅圏における CLy の特化係数 $)=(\mathrm{x}$ 駅圈におけるCLy の占める割合 $) /($ 全 駅圈における CLy の占める割合 $) \cdot ・ ・($ 式 3)

\section{参考文献}

1) Yoshinori Date (Edt.): City planning for beginners, Shin Aeba (et al.), Ichigaya Shuppan, 2008 (in Japanese)

伊達美徳編集：初めて学ぶ 都市計画, 饗庭伸・他, 市ヶ谷出版社, 2008

2) Naomichi Ishige: Talk about Food Culture, Domesu Shuppann, 2009

(in Japanese)

石毛直道：食の文化を語る，ドメス出版，2009

3) Tokyo Metropolitan Government: Tokyo government desided "Tokyo: To be the city with global brand power of tourism", http://www. metro. tokyo. jp/INET/KEIKAKU/2013/05/DATA/70n5m107. pdf, 2013 (in Japanese) 東京都：「世界の観光ブランド都市・東京をめざして」を策定, http：// www. metro. tokyo. jp/INET/KEIKAKU/2013/05/DATA/70n5m107. pdf， 2013, (accessed 2016. 9. 20)

4) Takao Mori: Food culture and food service industry, Naomichi Ishige4 and Tadashi Inoue, Lecture about Food Culture-Information of Food, Ajinomoto Foundation for Dietary Culture, 1999 (in Japanese)

森孝郎：食の文化と外食産業, 石毛直道, 井上忠司, 講座 食の文化 食の 情報化，公益財団法人 味の素食の文化センター, 1999

5) Yusuke Okada and Norihiro Nakai: A Study on Factors of Urban Commercial Development in Terms of Urban Tourism -An Analysis with Tour Guidebooks and Restaurants Guide in Case of Tokyo 23 Wards, Papers on city planning 38(3), pp. 583-588, 2003-10-25 (in Japanese) 岡田裕介, 中井検裕：都市観光から見た都心商業地の発展条件に関する研 究一東京 23 区を対象とした観光ガイド及びレストランガイドを用いた分析一, 都市計画論文集 38(3)，pp. 583-588，2003. 10. 25

6) LEE Donghoon: LOCATION OF STORES IN THE REGIONAL COMMERCIAL AREA : A case study of Shimokitazawa, Journal of Architecture and Planning (Transactions of AIJ), Vol. 73, No. 625, pp. 619-624, 2008. 3

(in Japanese)

李東勲：地域型商業地における店舗の立地状況に関する研究-下北沢の事 例-, 日本建築学会計画系論文集，Vol。73，No. 625，pp．619-624，2008，
3

7) Toru Kobayashi: A Study on the Experience of Landscape and Gustation, Infrastructure planning review, No. 13, pp. 511-516, 1996. 8 (in Japanese)

小林亨：飲食行為を伴う景観体験に関する考察-味覚風景論序説一, 土木計画 学研究・論文集, No. 13, pp. 511-516, 1996. 8

8) Yuki Tanabe and Kayoko Kaneko: Factors Influencing the Feeling of Satisfaction with Eating, Journal of Home Economics of Japan, Vol. 149, No. 9, pp. 1003-1010, 1998. 9 (in Japanese)

田辺由紀, 金子佳代子：食の満足感構成要素の構造, 日本家政学会誌, Vol. 49, No. 9, pp. 1003-1010, 1998. 9

9) Yuki Tanabe and Kayoko Kaneko: Factors Affecting a Feeling of Satisfaction about Eating among College Students, Journal of Home Economics of Japan, Vol. 52, No. 9, pp. 839-848 2001. 9

(in Japanese)

田辺由紀，金子佳代子：大学生における食の満足感に影響を及ぼす因子, 日本家政学会誌, Vol. 52, No. 9, pp. 839-848, 2001.9

10) Yuji Watanabe, Mizuki Otaki and Reiko Tsuji, Toru 0ta: Study of Eating Information in Japanese Female College Students(Factors Affecting Eating Behavior Part 3), Journal for the Integrated Study of Dietary Habits, Vol. 14, No. 1, pp. 28-35, 2003-2004

(in Japanese)

渡辺雄二, 大瀧未鶴希, 辻玲子, 太田徹: 女子学生の食行動に及ぼす食情 報の影響，日本食生活学会誌，Vol. 14, No. 1，pp. 28-35，2003-2004

11) Shenshen Gui, Ryoji Ito and Hitoshi Aoyagi: Consumer Behavior of Food Away from Home in Urban China-Based on the consumer Questionnaires in Beijing-, Journal of Rural Problems, Vol. 48, No. 3, pp. 374-385, 2012. 12 (in Jappanese)

桂棽棽, 伊藤亮司, 青柳斉：中国大都市における外食消費行動の分析一北 京市の住民調査から-，農林業問題研究，Vol. 48, No. 3, pp. 374-385, 2012. 12

12) Naoko Ishikawa and Ayako Ehara: Modern and Contemporary Food Culture, Kougaku Shuppann, 2000 (in Japanese)

石川尚子, 江原絢子：近現代の食文化, 弘学出版, 2000

13) Akio Saito: Chlonorogy of Japanese Eating Habits, Rakuyu Shobo, 1983 (in Japanese)

西東秋男：日本食生活史年表，楽游書房，1983

14) Akio Saito: Chlonorogy of Heisei Eating Habits, Tsukuba Shobo, 2012 (in Japanese)

西東秋男：平成食文化史年表，筑波書房，2012

15) Ayako Ehara and Naoko Ishikawa: Japanese Food Culture-Tradittion and Education-, I \& K Corporation, 2009 (in Japanese) 江原絢子, 石川尚子：日本の食文化一その伝承と食の教育, アイケイコーポ レーション, 2009

16) Tomokazu Kurita and Tomonori Takeuchi: Food culture revolution in the Internet age: Gourmet Navigater, The impact of the web site with ten million menbers, City planning review, Vol.304, The City Plannnig Institute of Japan, 2013 (in Japanese)

栗田朋一，竹内則友：ネット時代の食文化革命 ぐるなび 1000 万会員ウェ ブサイトのインパクト, 都市計画, 304 号, 公益財団法人日本都市計画学 会, 2013

17) Shun Yoshie, Haruhiko Goto and Shu Yamamura: Spatiotemporal Transformation of Narrations in Housing Advertisements as the Representations of Values of Living Environment within the Tokyo Metroporitan Area, Journal of Architecture and Planning (Transactions of AIJ), Vol. 80, No. 716, pp. 2231-2241, 2015. 10 (in Japanese) 吉江俊, 後藤春彦, 山村崇：首都圈における住環境の価值表現としての 住宅広告の「語り」の時空間的動態, 日本建築学会計画系論文集, Vol. 80, No . 716, pp .2231-2241，2015. 10 


\title{
THE GEOGRAPHICAL CHARACTERISTICS OF RESTAURANT DISTRIBUTION \\ AND EATING INFORMATION WITHIN TOKYO WARDS AREA
}

\author{
Tomoha ISHIWATA ${ }^{* 1}$, Haruhiko GOTO ${ }^{* 2}$ and Shun YOSHIE ${ }^{* 3}$ \\ ${ }^{* 1}$ Grad. Student, Graduate School of Creative Sci. \& Eng., Waseda Univ. \\ *2 Prof., Faculty of Creative Sci. \& Eng., Waseda Univ., Dr.Eng. \\ ${ }^{*}$ JSPS Fellow/Grad. Student, Dept. of Creative Sci. \& Eng., Waseda Univ., M.Arch.
}

In Tokyo, the accumulation of various restaurants is realized as resources of food culture. Nowadays, "eating experiences" in restaurants is getting important. However, the study on the quality of eating experiences and its geographical characters has hardly been conducted. Thus, it is important to reveal the empirical value of eating in the urban area. The purpose of this study is to identify the geographical characteristics of restaurants accumulation and "eating experiences" within Tokyo wards area. Through this research, the following has been identified:

\section{1) The distribution characteristics of restaurants accumulation}

In the $3^{\text {rd }}$ chapter, the correlations among the geographical distribution trend of 19 types of restaurants were revealed. They were divided into 3 similar groups and 7 independent groups. Then these accumulations were categorized into 3 similar groups. "Types with correlation between diner (A. - E.)" accumulated along Yamanote line and the linear area spreading from central Tokyo area to Shibuya area. "F. Traditional food and Japanese Food" accumulated into northern Tokyo wards area. "G. Soba and Udon and Chinese Food" accumulated into eastern Tokyo wards area.

Second, the accumulation characteristic of all restaurants was figured out and it became clear that restaurants accumulated in 5 areas; (a) area with some parallel lines in Tokyo wards area, (b) lines from Shinjuku to eastern wards area, (c) lines from Shibuya to eastern wards area, (d) around Ikebukuro, and (e) some station areas on the suburban railroads. Third, based on these characteristics of restaurants accumulation and the number of passengers, station areas could be divided into 4 similar groups; (a) Multiple types, Few passengers, (b) Multiple types, Many passengers, (c) Single type, Few passengers, and (d) Single type, Many passengers.

\section{2) The typology of eating experiences and its differences among station areas}

In the $4^{\text {th }}$ chapter, station areas with noticeable trend of each groups based on the characteristics of restaurants accumulation and the number of passengers were extracted. These were 9 station areas, which are Keiseiueno, Uenookachimachi, Shinjuku, Shibuya, Higashishinjuku, Daikanyama, Kitasenju, Ohtemachi, and Meguro. Second, regional characteristics based on "eating experience" were cleared. As a result, 82 types of enjoyable "eating experience" in Tokyo wards area were extracted. Then, they are divided into "contents (32)", "spaces (26)", "events (15)" and "surroundings (9)". With respect to "contents", Higashishinjuku and Daikanyama shows original trend but others didn't have distinguished trend. With respect to "spaces", there were no differences by station areas. With respect to "events", there were no differences by station areas without Higashishinjuku and Ohtemachi. With respect to "surroundings", it was identified that the "surroundings" is the most unique "earing experiences" which differs by station areas. Then, summarizing characteristics of station areas based on these 4 "eating experiences", 5 regional characteristics based on specialized cluster within "contents" and extra specialization in eating experiences were identified; (a) enjoy contents (Uenookachimachi and Higashishinjuku), (b) enjoy alcoholic drink and spaces, (c) enjoy ambience, (d) enjoy events, and (e) enjoy location and night view. These characteristics were different from those we have seen in the analysis of restaurants accumulation and the number of passengers. Therefore these were unique characteristics seen from "eating experiences". 